\title{
Nilai Penting Kawasan Depresi Walennae, Kabupaten Soppeng, Sulawesi Selatan
}

\author{
Muhammad Nur \\ Jurusan Arkeologi Universitas Hasanuddin.
}

Email : aaaaaa

\begin{abstract}
Abstrak: Artikel ini difokuskan pada pengidentifikasian nilai penting kawasan Depresi Walennae dan situs-situs yang ada di dalamnya. Konsep nilai penting yang dipakai adalah Pasal 5 Undang-undang Nomor 11 Tahun 2010 tentang Cagar Budaya. Baik dalam skala kawasan Depresi Walennae yang luas maupun skala situs, nilai penting yang paling menonjol adalah nilai ilmu pengetahuan, meliputi nilai arkeologi, geologi, sedimentologi, paleontologi, paleo-antropologi, dan biologi. Dengan demikian, pemanfaatan yang tepat untuk kawasan Depresi Walennae dan situs-situs di dalamnya adalah pemanfaatan yang berhubungan dengan ilmu pengetahuan.
\end{abstract}

Kata kunci: Walennae, Celebochoerus heekereni, Stegodon sompoensis.

Abstract: This article is focused on identifying significance value of Depression Walanae and its cultural heritage sites. The concept of significance value used is the one included in National Law No. 11 of 2010 about Cultural Heritage. Both in wider and particular areas of Walennae Depression, the most significant value is the value of science, including the value of archeology, geology, sedimentology, paleontology, paleo-anthropology, and biology. Thus, the proper utilization of the region Walennae Depression and its sites is related to the utilization of science.

Keywords: Walennae, Celebochoerus heekereni, Stegodon sompoensis.

\section{Pendahuluan}

Penelitian non manajemen sumberdaya arkeologi (baca arkeologi murni) telah dilakukan sejak tahun 1947 di kawasan Depresi Walennae. Ahli yang berjasa meletakkan perspektif penelitian Paleolitik di Pulau Sulawesi adalah Robert van Heekeren, meskipun Sarasin bersaudara adalah peneliti pertama yang menginformasikan keberadaan artefak batu masif dari Cabbenge dalam bukunya Reisen in Celebes tahun 1905. Hasil penelitian van Heekeren diulas dalam karya sintesisnya berjudul The Stone Age of Indonesia yang terbit pada tahun 1972 yang menyebut kawasan Depresi Walennae sebagai Cabbenge Flakes Industry. Selain artefak batu,juga ditemukan fosil binatang vertebrata seperti Archidiskodon celebensis, Stegodon sompoensis, Celebochoerus heekereni, Anoa depressicornis dan Testudo Margae ${ }^{1}$ [Heekeren,1972:64-71]. Meskipun tidak kontinyu, penelitian arkeologi, geologi, paleontologi, dan sedimentologi masih terus dilakukan sampai sekarang, baik oleh ahli manca negara maupun dalam negeri.

(MSA) di situs-situs kawasan Depresi Walennae lebih banyak dilakukan oleh BPCB Makassar dan mahasiswa Jurusan Arkeologi Universitas Hasanuddin, Makassar. Meskipun sudah mendapat tindakan pelestarian secara proporsional, seperti penempatan beberapa juru pelihara atau sosialisasi Undang-undang

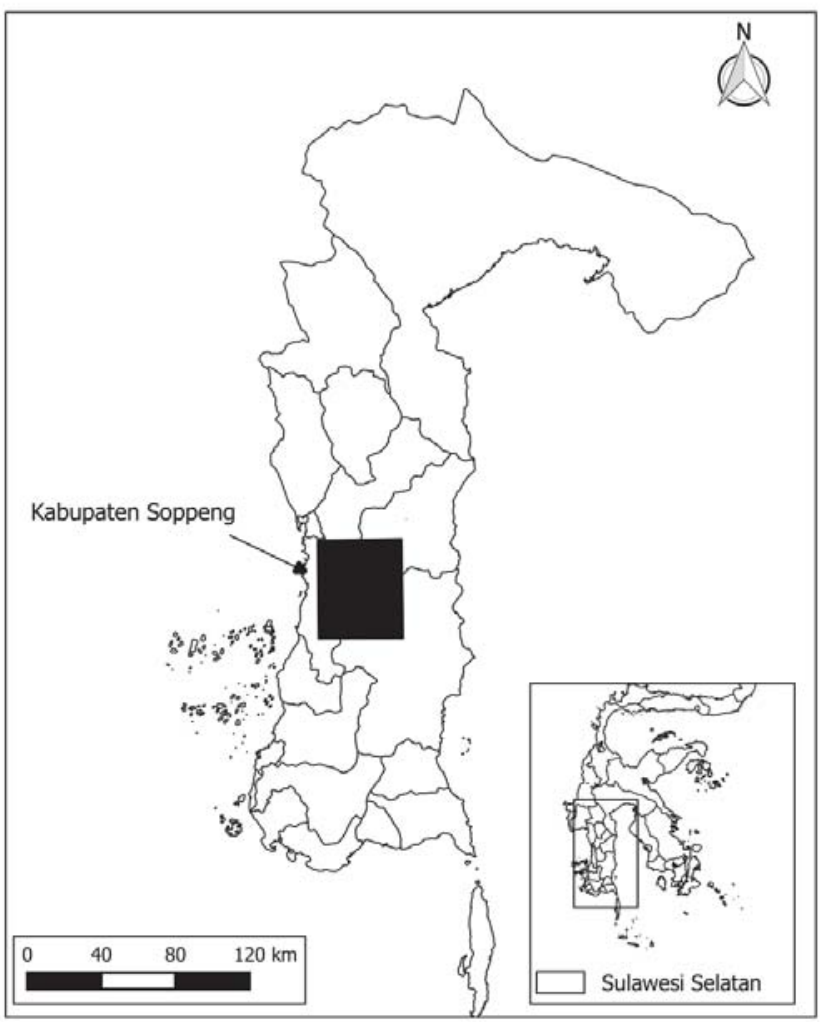

Peta 1. Posisi lokasi penelitian, Penelitian manajemen sumberdaya arkeologi (Sumber : Nur)

\footnotetext{
${ }^{1}$ Testudo margae adalah kura-kura raksasa yang oleh para ahli sekarang diganti namanya menjadi Geocelone atlas
} 


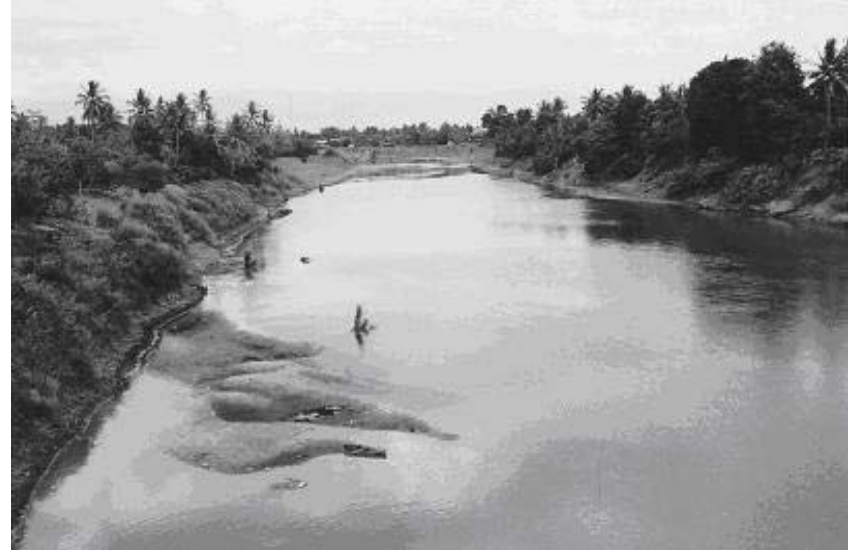

Foto 1. Sungai Walennae yang membelah Depresi Walennae Purba (Sumber: Nur).

no.10 tahun 2011 (Selanjutnya disebut Undang-undang Cagar Cagar Budaya) tetapi kondisi di lapangan masih jauh dari harapan. Memang tingkat kerumitan dalam melestarikan situs terbuka dengan luasan lebih dari 50 $\mathrm{km}$ panjang dengan lebar sekitar enam sampai $14 \mathrm{~km}$ sangat sulit. Untuk berpartisipasi dalam upaya pelestarian dan pemanfaatan situs kawasan ini, artikel ini diajukan. Artikel ini akan mendiskusikan garis besar nilai penting kawasan Depresi Walennae dan situs-situs di dalamnya.

\section{Rumusan Masalah}

Fokus diskusi dalam artikel ini adalah nilai penting Kawasan Depresi Walennae. Ada pun pertanyaan penelitian yang diajukan adalah :

a. Apa nilai penting yang dikandung oleh kawasan Depresi Walennae berdasarkan undang-undang Cagar Budaya no.10 tahun 2011 ?

b. Apa nilai penting yang dikandung oleh situssitus yang terdapat di dalam kawasan Depresi Walennaeberdasarkan undang-undang Cagar Budaya no.10 tahun 2011 ?

Kedua pertanyaan di atas merujuk pada nilai penting berdasarkan undang-undang Cagar Budaya no.10 tahun 2011. Acuan regulasi ini dipilih supaya cara pandangnya lebih sesuai dengan cara pandang pihak pelestari di Indonesia dalam mengambil langkah pelestarian dan pemanfaatan di masa mendatang.

\section{Metode Penelitian}

Penelitian lapangan telah dilakukan pada situs kawasan Depresi Walennae dan delapan lokasi konsentrasi temuan (situs) yang ada di dalamnya. Data yang banyak dijumpai adalah artefak batu, fosil binatang vertebrata, dan singkapan stratigrafi tanah. Identifikasi bentuk dan sebaran secara horizontal dan vertikal adalah fokus diskusi dalam artikel ini. Untuk melengkapi hasil studi lapangan, penelitian pustaka juga dilakukan. Dalam menganalisis nilai penting, konsep yang dirujuk adalah Pasal 5 Undang-undang no.11 Tahun 2010 tentang Cagar Budaya. Pada tahap akhir, dilakukan penilaian kualitatif dalam tingkat kawasan dan situs untuk menemukan alasan dalam menentukan fokus pelestarian dan pemanfaatan di masa mendatang.

\section{Nilai Penting Situs Kawasan Depresi Walennae}

Sampai sekarang, Lembah Sungai Walennae merupakan salah satu kawasan di Sulawesi Selatan yang memiliki peninggalan arkeologi dari Kala Pleistosen. Berdasarkan penelitian beberapa sarjana sejak tahun 1947 sampai sekarang, dapat disepakati bahwa Depresi Walennae Purba mewakili umur geologi dari Kala Plestosen sampai Kala Holosen. Pada Depresi Walennae purba tersebut, terdapat lebih dari sepuluh titik konsentrasi artefak yang kemudian oleh para ahli dijadikan acuan utama untuk menyebutnya sebagai situs arkeologi.

Pada kenyataannya, kita hampir tidak memiliki alasan geologi dan bio-stratigrafi untuk membedakan situs arkeologi di dalam kawasan Depresi Walennae karena semua titik-titik konsentrasi artefak tersebut sampai pada kondisinya sekarang adalah akibat dari proses pertumbuhan [genesis] dan pembentukan [forming] yang sama dan sulit ditentukan batasannya. Oleh karena itu, kita tidak perlu heran bila menemukan suatu nama situs dan besarannya yang berbeda antara satu versi penelitian dengan versi penelitian lain. Satu-satunya

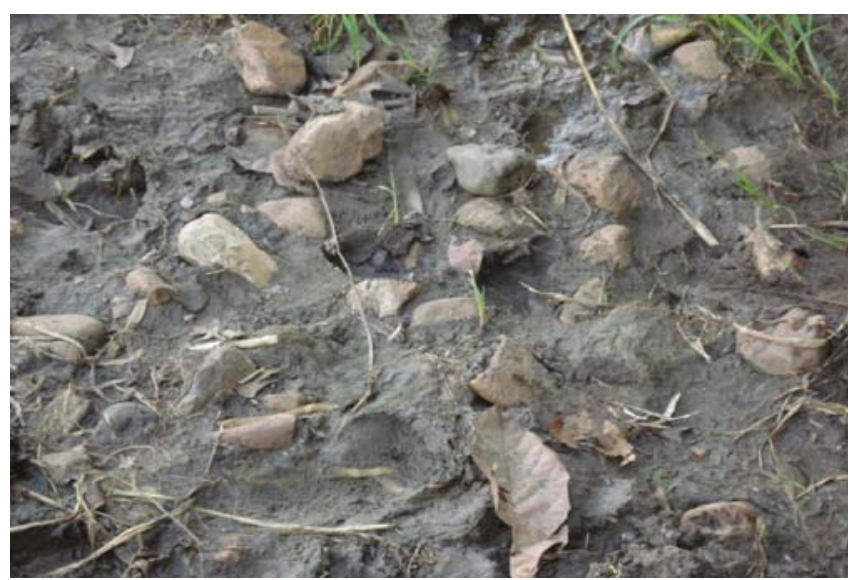

Foto 2. Sebaran artefak batu masif di Depresi Walennae (Sumber: Nur) 


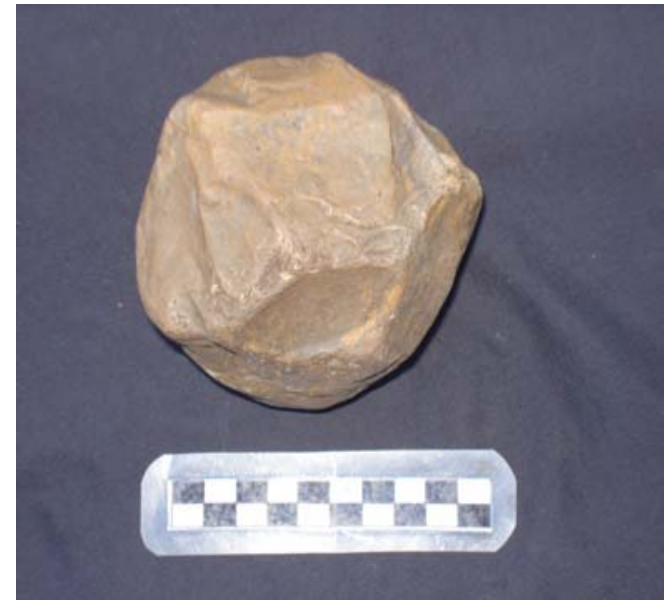

Foto 3. Kapak penetak dari situs Talepu (Sumber: Nur)

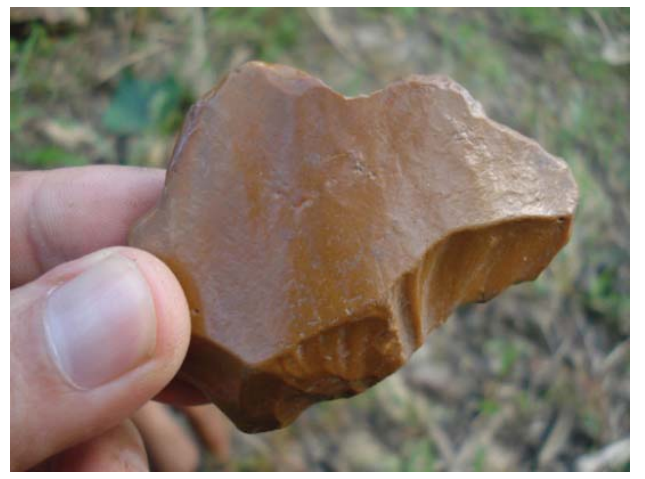

Foto 4. Alat serpih dari situs Talepu (Sumber: Nur).

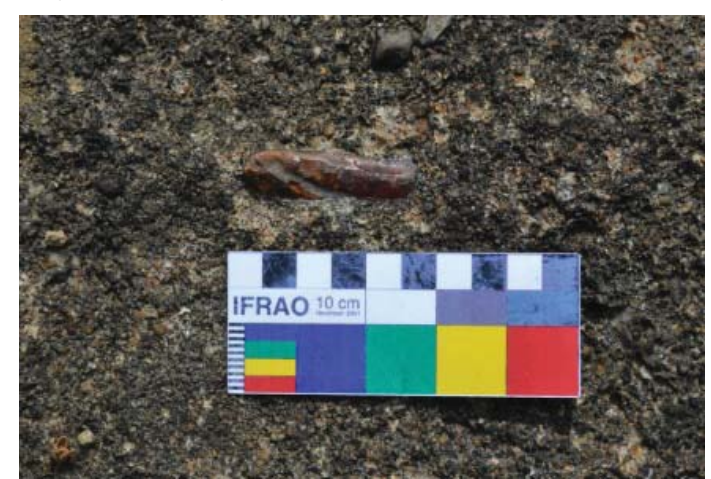

Foto 5. Taring Celebochoerusyang masih melekat dalam lapisan konglomerat di situs Calio (Sumber: BPCB Makassar)

alasan yang dapat diajukan adalah alasan arkeologis, itu pun jika penelitian arkeologi dapat mengungkap karakter spesifik dan tahapan [sequence] dari setiap titik konsentrasi artefak [situs]. Penyebutan titik konsentrasi artefak menjadi situs dalam penelitian ini didasarkan pada pertimbangan administratif dan naratif saja agar dalam upaya pengelolaan, langkah efektif dan strategis dapat lebih leluasa dilakukan untuk melestarikan beberapa titik konsentrasi artefak [situs] yang dianggap mendesak ditangani.

Berdasarkan argumentasi di atas, justifikasi terhadap nilai penting dari Kawasan Depresi Walennae

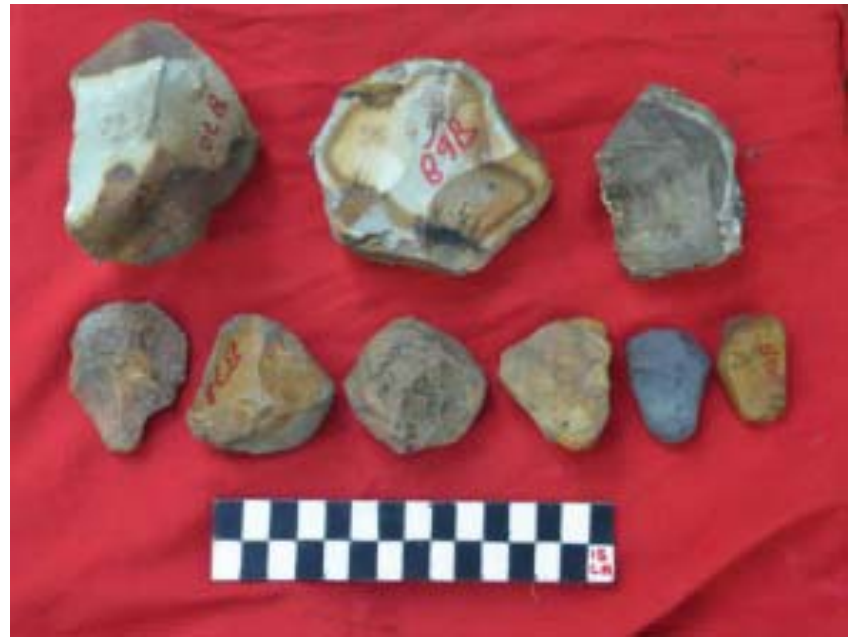

Foto 5. Artefak batu masif dari situs Jampu (Sumber: BPCB Makassar)

dalam artikel ini selayaknya dianggap satu. Hal ini tidak berarti kita menutup kemungkinan untuk membedakannya di masa mendatang. Berdasar pada hasil pengumpulan dan pengolahan data pada penelitian ini, yang kemudian dielaborasi dengan hasil penelitian ahli terdahulu, saya akan merangkum beberapa nilai penting yang dikandung oleh Kawasan Depresi Walennae dalam satu kesatuan. Meskipun demikian, terdapat penekanan pada bagian akhir tentang karakter setiap situs di dalam Depresi Walennae dengan maksud untuk memudahkan mengambil keputusan dalam membuat prioritas pelestarian di kawasan ini.

Konsep nilai penting yang digunakan dalam penelitian ini adalah nilai penting yang digariskan dalam Pasal 5 Undang-undang Republik Indonesia Nomor 11 Tahun 2010 tentang Cagar Budaya. Pemakaian regulasi ini sangat beralasan secara akademis, aplikatif, politis, maupun administratif. Adapun bunyi Pasal 5 UU No.11 Tahun 2010 tentang Cagar Budaya tersebut adalah Benda,

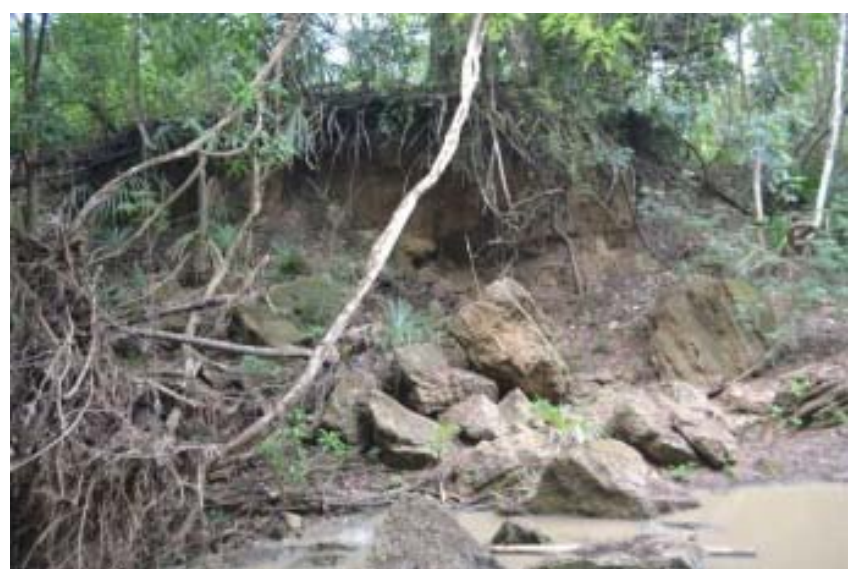

Foto 6. Singkapan stratigrafi pinggiran Sungai Walennae yang mengandung artefak batu dan fosil binatang vertebrata.

(Sumber: BPCB Makassar) 
bangunan, atau struktur dapat diusulkan sebagai Benda Cagar Budaya, Bangunan Cagar Budaya, atau Struktur Cagar Budaya apabila memenuhi kriteria:

1. berusia 50 (lima puluh) tahun atau lebih;

2. mewakili masa gaya paling singkat berusia 50 [lima puluh] tahun;

3. memiliki arti khusus bagi sejarah, ilmu pengetahuan, pendidikan, agama, dan/atau kebudayaan; dan

4. memiliki nilai budaya bagi penguatan kepribadian bangsa.

Regulasi tersebut, secara jelas menyatakan bahwa nilai penting Cagar Budaya adalah nilai penting sejarah, ilmu pengetahuan, pendidikan, agama, dan atau kebudayaan.

Kawasan Depresi Walennae yang mengandung banyak situs diasumsikan mengandung nilai penting sejarah karena hasil penelitian yang pernah dilakukan para ahli telah berhasil menempatkan kawasan ini sebagai salah satu dari sedikit situs Paleolitik di Indonesia, dan bahkan menjadi situs Paleolitik tertua di Pulau Sulawesi. Dari segi teknologis, morfologis, patinasi, dan intensitas pembundaran artefak, artefak batu dari kawasan ini dapat dibagi dua ${ }^{2}$ yaitu pertama, alat batu Paleolitik yang berteknologi masif dengan patinasi tebal dan sudah mengalami proses pembundaran tingkat tinggi, serta kedua, alat batu yang berumur lebih mudah dengan ciri teknologi serpih bilah yang lebih halus dan belum mengalami proses pembundaran serta berpatinasi tipis. Kategori pertama terdiri dari jenis artefak batu dari bagian inti [core tools] seperti hand axe, chopper, chopping tool, hand adze, dan jenis artefak serpihan [flakes] seperti scraper, blade, atau point. Kategori kedua meliputi jenis artefak berukuran lebih kecil dengan teknologi yang lebih halus dan rumit seperti scraper, blade, point, dan mikrolit. Soejono [1991] beranggapan bahwa alat batu kategori tersebut memperlihatkan kemiripan dengan teknologi Clacton, sedangkan Bulbeck (2008) mengelompokkannya sebagai peninggalan Toala bagian utara-timur, yang dideskripsi sebagai a less complex forager occupation, dengan wilayah okupasi sepanjang aliran sungai Walennae dan pesisir timur [Bulbeck,2008:187]. Meskipun tanpa pertanggalan absolut, pengelompokan dua industri alat batu yang dikandung oleh Kawasan Depresi Walennae membuktikan perkembangan industri alat batu purba yang menjadi dasar pemahaman teknologi alat batu pada masa selanjutnya. Situs Kawasan ini adalah penyumbang dua tahapan awal dari beberapa tahapan sejarah kebudayaan di Pulau Sulawesi.

Kawasan Cabbenge diasumsikan mengandung nilai penting ilmu pengetahuan karena memiliki potensi untuk diteliti pada masa mendatang, terutama pada bidang ilmu arkeologi, geologi, sedimentologi, paleontologi, paleoantropologi, dan biologi.

a. Nilai penting arkeologi tergambarkan dari penelitian arkeologi yang dilakukan terus menerus sejak tahun 1947 oleh van Heekeren, sampai sekarang. Beberapa arkeolog garda depan yang mencantumkan pentingnya Situs Kawasan Cabbenge dalam karyanya adalah van Heekeren dalam bukunya The Stone Age of Indonesia [1972], R.P. Soejono dalam Sejarah Nasional Indonesia I [1991], Peter Bellwood dalam Prehistoryof The IndoMalaysian Archipelago [1985], Bulbeck dalam Austronesian in Sulawesi [2008] dan sejumlah artikel ilmiah yang lahir, baik di dalam negeri maupun di luar negeri. Beberapa penelitian di atas menunjukkan potensi situs kawasan ini dalam melengkapi penjelasan tentang sejarah budaya umat manusia.

b. Nilai penting geologi dikandung oleh kawasan ini terutama sumbangannya untuk memperkaya kajian geologi tertier dan geologi kuarter. Beberapa penelitian geologi telah dilakukan seperti oleh Barstra [1977] yang menghasilkan artikel berjudul Walanae Formation and Walanae terraces in the stratigraphy of South Sulawesi (Celebes, Indonesia), atau artikel Sjahroel, A.A. [1970] berjudul Report on the preliminaty geological survey of the central part of Kabupaten Soppeng, South Celebes. Selain memperkaya kajian pure science, kajian geologi pada wilayah ini memiliki posisi penting dalam membantu penjelasan tentang proses pembentukan Pulau Sulawesi, sekaligus memandu arkeologi dalam merekonstruksi

${ }^{2}$ Pembagian artefak batu Cabbenge menjadi dua juga pernah diusulkan oleh Barstra [1978] dan R.P. Soejono [1991]. 


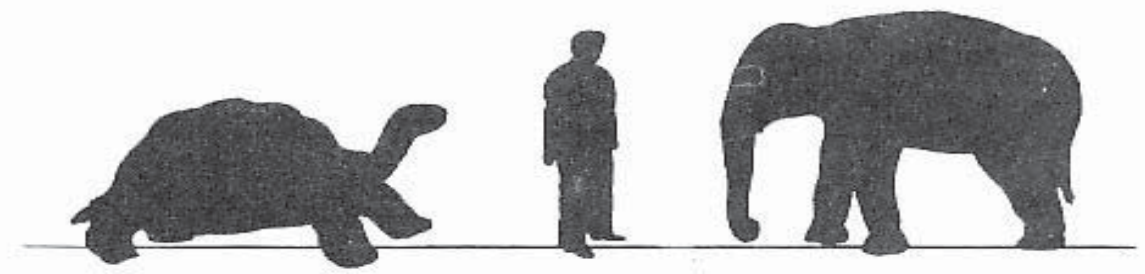

Gambar 1. Ukuran relatifPigmy stegodon, kura-kura raksasa, dan manusia dengan tinggi 1,65 m. (sumber: A.J. Whitten,1987).

masa Paleolitik di dalam Kawasan ini.

c. Nilai penting sedimentologi dikandung oleh kawasan ini karena dibentuk oleh proses pengendapan, baik endapan sungai, endapan akibat erosi maupun endapan danau. Selain untuk pure science, kajian sedimentologi kawasan ini penting dikembangkan terutama yang berhubungan dengan kajian tata guna lahan.

d. Nilai penting paleontologi Kawasan Depresi Walennae dibuktikan oleh banyaknya penelitian, seperti yang dilakukan oleh Barstra [1978] dengan laporan berjudul Note on new data concerning the fossil vertebrates and stone tools in the Walanae Valley in South Sulawesi [Celebes], Peter Bellwood [1985] dengan buku berjudul Prehistory of the Indo-Malaysian archipelago, Hooijer, D.A. [1948] dengan laporan berjudul Pleistocene vertebrates from Celebes: Celebochoerus heekereni nov.gen.nov.spec., S. Sartono, [1979] dengan artikel berjudul The age of the vertebrate fossils and artefacts from Cabenge in South Sulawesi, Indonesia, P.Y. Sondaar, [1981] dalam artikel berjudul Geochelone faunas of the Indonesian archipelago and their paleographical and biostratigraphical significance.

Penelitian paleontologi di atas telah berhasil memberikan penjelasan tentang jalur migrasi fauna plio-plestosen dari daratan Asia seperti gajah yang melampaui Garis Wallace. Beberapa fauna endemik Sulawesi seperti anoa dan babi rusa juga dapat ditelusuri leluhurnya dari kawasan Depresi Walennae ini.

e. Nilai penting Paleoantropologi kawasan

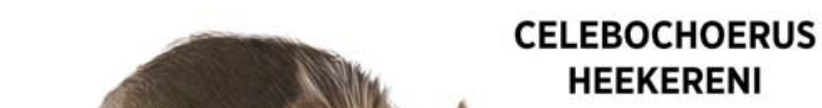

Gambar 2. Hasil rekonstruksi fosil Celebochoerus heekereni

(Sumber: National Geographic Indonesia)

Depresi Walennae telah diteliti secara terintegrasi dengan penelitian arkeologi, geologi, paleontologi dan ilmu lain tetapi belum menghasilkan satu fragmen fosil manusia purba sampai sekarang. Hipotesis tentang keberadaan manusia purba di situs kawasan ini sangat kuat karena didukung oleh data artefaktual dan data geologi. Melihat teknologi artefak batu Paleolitik dan sebarannya pada endapan Plestosen, para ahli berpendapat bahwa kehadiran manusia purba sangat jelas. Oleh karena itu, dengan mempertimbangkan posisi Pulau Sulawesi dalam jalur migrasi manusia purba di Asia, riset pencarian fosil manusia purba sangat penting di situs kawasan ini. Kuat dugaan bahwa penemuan manusia purba di Sulawesi akan memiliki impactyang hebat terhadap debat sejarah genetika dan evolusi dari Homo floresiensis, yang sangat mungkin menjangkau Flores melalui Sulawesi [Morwood dan van Oosterzee,2007].

f. Nilai penting biologi dikandung oleh 
kawasan Depresi Walennae karena selain binatang purba yang telah diulas pada nilai penting paleontologis, pollen vegetasi purba tentunya terdapat pada endapan danau dan Sungai Walennae Purba. Anthony J. Whitten [1978] dalam buku Ekologi Sulawesi sepintas telah mengulas aspek ini. Potensi situs kawasan ini sangat signifikan untuk mengetahui vegetasi purba Sulawesi.

Kawasan Depresi Walennae diasumsikan mengandung nilai penting pendidikan karena berpotensi besar sebagai lokasi praktek lapang dalam pengkayaan teori yang diperoleh oleh siswa dan mahasiswa di kelas. Potensi pendidikan ini semakin besar karena tersedianya Museum Situs Calio yang menjadi lokasi penyimpanan dan pameran temuan fosil dan artefak batu. Berdasarkan buku tamu Museum Calio, rombongan mahasiswa Jurusan Arkeologi Universitas Hasanuddin melakukan kunjungan setiap tahun dalam 25 tahun terakhir, ditambah mahasiswa Jurusan Sejarah Universitas Negeri Makassar, serta siswa sekolah menengah atas dari berbagai daerah. Data ini menunjukkan nilai penting pendidikan yang tinggi dan sangat potensial dikembangkan di masa mendatang.

Kawasan Depresi Walennae diasumsikan mengandung nilai penting kebudayaan karena akan memperkaya identitas sejarah kebudayaan Sulawesi Selatan. Kawasan ini mewakili hasil pencapaian budaya purba jaman Paleolitik Sulawesi Selatan. Tentunya, keberadaannya telah membawa kebanggaan masyarakat

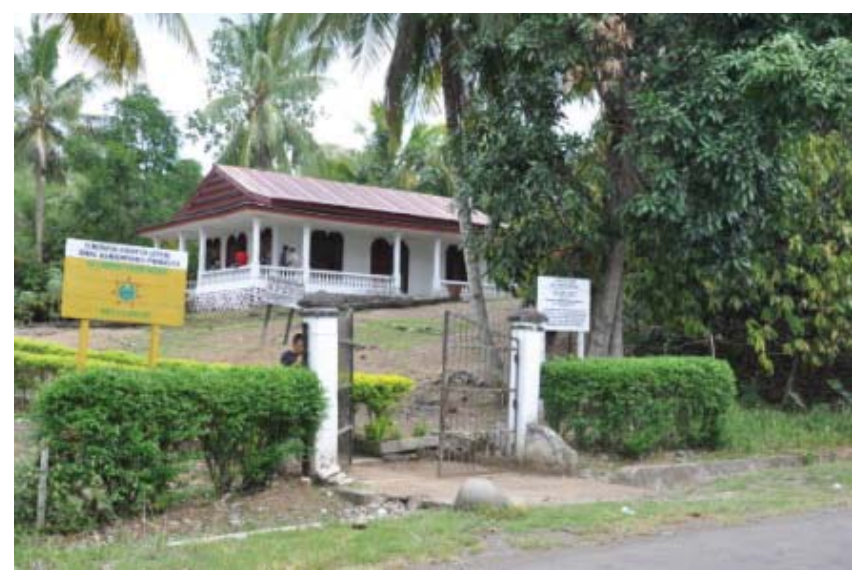

Foto 7. Museum Calio, Kabupaten Soppeng (Sumber: BPCB Makassar) yang secara otomatis akan menguatkan budaya masyarakat Sulawesi Selatan dalam konteks waktu sekarang dan masa yang akan datang.

\section{Karakter Situs dan Perbedaan Nilai Penting}

Sudah dijelaskan sebelumnya bahwa secara akademis, kawasan Depresi Walennae harus dilihat sebagai satu kesatuan, namun untuk keperluan naratif, administratif, efektivitas, dan aplikatif, kawasan ini akan dibagi menjadi delapan situs yaitu Situs Berru, Marale, Paroto, Kecce, Salaonro, Jampu, Lakibong, dan Lenrang. Kedelapan situs ini memiliki perbedaan kandungan data dan juga nilai penting. Dari hasil identifikasi karakter situs tersebut, diasumsikan bahwa langkah-langkah pelestarian dan penelitian yang melatarinya dapat disusun lebih terarah dan berbasis pada kebutuhan.

\section{a. Situs Berru}

Berdasarkan hasil penelitian dari situs ini, data yang dapat dirangkum adalah temuan artefak batu, fosil binatang vertebrata, batuan konglomerat yang mengandung fosil dan alat batu masif, singkapan tanah hasil sedimentasi sungai purba, tembikar, keramik asing, dan batu lumpang. Artefak batu yang ditemukan serta yang dilaporkan oleh peneliti sebelumnya adalah dominan artefak batu masif berukuran sedang dan kecil ${ }^{3}$, sedangkan artefak batu Toala tidak ditemukan pada situs ini. Situs ini juga didiami oleh masyarakat yang turun temurun mengelola lahan sekitar dengan mata pencaharian utama sebagai petani sawah dan kebun.

Berdasar pada data di atas, nilai penting Situs Berru lebih menonjol pada nilai ilmu pengetahuan, terutama pada bidang ilmu paleontologi, arkeologi, geologi, sedimentologi, dan paleoantropologi. Keunikan dan kelangkaannya berada pada sebaran konglomerat yang mengandung fosil binatang vertebrata dan alat batu masif. Jenis data seperti ini sangat jarang ditemukan dan memiliki potensi untuk menjawab perdebatan jalur migrasi manusia dan fauna purba di Asia Tenggara dan Australia.

Oleh karena itu, berdasarkan nilai penting di atas, fokus perlakuan pelestarian dan penelitian sebaiknya dilakukan pada beberapa titik yaitu Bulu Lampu, Calio,

3 Untuk membedakan artefak batu masif antara satu situs dengan situs lain, dilakukan pembagian berdasarkan ukuran menjadi tiga bagian yaitu besar, sedang dan kecil. Dimaksudkan sebagaiartefak batu ukuran kecil antara 1,5-5,0 cm, ukuran sedang antara 5,1-9,0 cm, dan ukuran besar adalah 9,1-14 cm. 
Bulu Pabeccenge, dan Calio Tua. Karena titik konsentrasi data pada situs ini cukup luas baik secara horisontal maupun vertikal, maka disarankan untuk fokus pada permukaan tanah di ketinggian antara 45 mdpl sampai 65 mdpl, dengan tetap mempertimbangkan kondisi singkapan tanah dan topografi setempat. Rentang titik ketinggian antara 45 mdpl sampai 65 mdpl ini memiliki potensi arkeologis dan paleoantropologis paling tinggi dibandingkan dengan permukaan tanah lainnya di dalam Situs Berru.

\section{b. Situs Marale}

Berdasarkan hasil penelitian dari situs ini, data yang dapat dirangkum adalah temuan artefak batu, fosil binatang vertebrata, batuan konglomerat yang mengandung fosil, alat batu masif, dan tembikar. Artefak batu yang ditemukan dalam penelitian penulis serta yang dilaporkan oleh peneliti sebelumnya adalah dominan artefak batu masif berukuran besar, sedang dan kecil, sedangkan artefak batu Toala tidak ditemukan pada situs ini. Situs ini juga didiami oleh masyarakat yang turun temurun mengelola lahan sekitar dengan mata pencaharian utama sebagai petani sawah dan kebun.

Berdasarkan pada data di atas, nilai penting Situs Marale lebih menonjol pada nilai ilmu pengetahuan, terutama pada bidang ilmu paleontologi, arkeologi, geologi, sedimentologi, dan paleoantropologi. Keunikan dan kelangkaannya berada pada beberapa bukit yang mengandung fosil binatang vertebrata dan alat batu masif terutama di Bulu Cepo1 dan 2, Bulu Tociapa, dan Bulu Cebo. Jenis data seperti ini sangat jarang ditemukan dan memiliki potensi untuk menjawab perdebatan jalur migrasi manusia dan fauna purba di Asia Tenggara dan Australia. Berasarkan pengamatan sebaran data, disarankan untuk fokus pada ketinggian antara $50 \mathrm{mdpl}$ - $65 \mathrm{mdpl}$ untuk penelitian arkeologis dan paleoantropologis, sedangkan untuk penelitian paleontologis pada ketinggian antara 65 mdpl - 95 mdpl. Dengan kata lain, ketinggian antara 50 mdpl - 65 mdpl memiliki nilai penting arkeologis dan paleoantropologis yang lebih tinggi, sedangkan ketinggian antara $65 \mathrm{mdpl}$ - $95 \mathrm{mdpl}$ lebih memiliki nilai penting paleontologi yang lebih tinggi.

\section{c. Situs Paroto}

Situs ini memiliki potensi data yang berbeda dengan situs Berru dan Situs Marale. Berdasarkan hasil penelitian dari situs ini, data yang dapat dirangkum adalah temuan artefak batu masif, batu lumpang, batu dakon, keramik, dan tembikar. Artefak batu yang ditemukan serta yang dilaporkan oleh peneliti sebelumnya adalah dominan artefak batu masif berukuran besar, dan sedang, serta artefak batu Toala yang menonjolkan teknologi penyerpihan yang lebih cermat dan ukuran yang lebih kecil. Situs ini juga didiami oleh masyarakat yang turun temurun mengelola lahan sekitar dengan mata pencaharian utama sebagai petani sawah dan kebun.

Sama dengan situs lain di kawasan Depresi Walennae, Situs Paroto lebih menonjol pada nilai ilmu pengetahuan, terutama pada bidang ilmu arkeologi, geologi, dan paleoantropologi. Hal yang agak menonjol dari situs ini adalah alat batu masif dalam ukuran besar lebih dominan. Titik-titik konsentrasinya adalah Bulu Jawi-jawi, Bulu Unane, Bulu Tanete, dan Bulu Bengkel. Data ini memiliki potensi untuk menjawab pertanyaan seputar teknologi alat batu Paleolitik serta kelanjutan unsur-unsurnya pada budaya Toala yang berumur lebih muda. Berdasarkan pengamatan sebaran data, disarankan untuk fokus pada ketinggian antara 35 mdpl - 55 mdpl untuk penelitian arkeologis dan paleoantropologis, sedangkan untuk penelitian geologi dan sedimentologi, dapat difokuskan pada singkapan tanah di pinggiran Sungai Walennae. Dengan kata lain, ketinggian antara $35 \mathrm{mdpl}$ - $55 \mathrm{mdpl}$ memiliki nilai penting arkeologis dan paleoantropologis yang lebih tinggi. Meskipun demikian, singkapan tanah yang ketinggiannya 29 m dpl pada pinggiran Sungai Walennae menunjukkan stratigrafi tanah serta temuan artefak batu di dalamnya yang sangat potensial, terutama untuk melihat kronologis teknologi alat batu di Sulawesi Selatan.

\section{d. Situs Lakibong}

Situs ini memiliki kuantitas dan variabilitas data yang paling sedikit dibanding situs lainnya di dalam Depresi Walennae. Adapun data yang berhasil dijaring adalah berupa artefak batu masif, konglomerat yang mengandung fosil binatang vertebrata, serta tembikar. Artefak batu masif ditemukan hanya pada satu titik di Jekkae, yang sebagian besar merupakan alat serpih dengan ukuran sedang dan kecil, itupun dalam kuantitas yang sedikit. Demikian pula dengan temuan tembikar, kuantitasnya juga sedikit tanpa titik konsentrasi.

Meskipun demikian, situs ini mengandung fosil vertebrata yang sangat kaya. Rekonstruksi fauna 
Celebochoerus beekereni oleh DR. Beren Kelly didasarkan atas temuan rangka utuh fosil hewan ini di Jekkae, satu titik yang memiliki kandungan data paleontologi sangat kaya. Beberapa fosil hewan purba yang pernah ditemukan dari situs ini adalah gajah, buaya, ikan hiu, dan babi rusa. Berdasar pada kandungan data ini, dapat diasumsikan bahwa nilai penting yang berarti dari situs ini adalah nilai penting ilmu pengetahuan terutama dalam bidang paleontologi, geologi, dan sedimentologi. Potensi arkeologi dan paleoantropologi tidak signifikan dari situs ini.

\section{e. Situs Kecce}

Situs ini hanya memiliki data artefak batu masif tetapi dalam jumlah yang banyak dan tipologinya yang beragam. Dari segi ukuran, artefak batu masif Situs Kecce dominan berukuran besar dan sedang. Berdasarkan distribusi temuan, titik konsentrasi temuan berada pada punggung bukit dengan ketinggian antara 30 mdpl - 40 mdpl. Nilai penting ilmu pengetahuan terutama bidang arkeologi dan paleoantropologi lebih menonjol pada situs ini.

\section{f. Situs Salaonro}

Situs ini memiliki data berupa artefak batu masif, artefak batu Toala, serta makam pada puncak bukit. Konsentrasi artefak batu berada di permukaan Bukit Allangkanangnge. Adapun ukuran alat batu masif adalah besar, sedang dan kecil dengan persentase yang merata. Titik ketinggian konsentrasi alat batu masif dan Toala adalah ketinggian antara $40 \mathrm{mdpl}-60 \mathrm{mdpl}$. Berdasarkan pada data tersebut, nilai penting yang menonjol pada situs ini adalah nilai penting ilmu pengetahuan terutama dalam bidang arkeologi dan paleoantropologi.

\section{g. Situs Jampu}

Situs Jampu hanya memiliki data artefak batu masif tetapi dalam jumlah yang banyak dan tipologinya yang beragam. Dari segi ukuran, artefak batu masif

Anonim, 2010, Undang-undang Republik Indonesia Nomor 11 Tahun 2010 tentang Cagar Budaya. Jakarta. DepDikNas.

Barstra, G.J. 1977, Walennae Formation and Walanae terraces in the stratigraphy of South Sulawesi, Celebes, Indonesia. Quartar 37/28:11-20.
Situs Jampu dominan berukuran besar dan sedang. Berdasarkan distribusi temuan, titik konsentrasi temuan berada pada punggung bukit dengan ketinggian antara 50 mdpl - 65 mdpl. Selama penelitian arkeologi di kawasan Depresi Walennae, Situs Jampu merupakan salah satu dari tiga situs yang memiliki koleksi kapak genggam (hand axe). Nilai penting ilmu pengetahuan terutama bidang arkeologi dan paleoantropologi lebih menonjol pada situs ini.

\section{h. Situs Lenrang}

Situs Lenrang memiliki data artefak batu masif dan artefak batu serpih bilah Toala. Jumlah temuan cukup banyak dan tipologinya juga beragam. Dari segi ukuran, artefak batu masif Situs Lenrang dominan berukuran besar dan sedang meskipun ukuran kecil juga ditemukan tetapi dalam jumlah yang tidak signifikan. Berdasarkan distribusi temuan, titik konsentrasi temuan berada pada Bulu Lenrang, di punggung bukit dengan ketinggian antara $25 \mathrm{mdpl}-55 \mathrm{mdpl}$. Nilai penting ilmu pengetahuan terutama bidang arkeologi dan paleoantropologi lebih menonjol pada situs ini.

\section{Kesimpulan}

Di antara beberapa nilai yang dikandung, nilai penting yang paling menonjol pada kawasan Depresi Walennae adalah nilai penting ilmu pengetahuan yaitu ilmu arkeologi, geologi, sedimentologi, paleontologi, paleoantropologi, dan biologi. Hasil penelitian lapangan dan pustaka seperti yang dirangkum di atas dapat mengarahkan kita untuk fokus pada titik-titik tertentu di permukaan tanah, baik secara horizontal maupun secara vertikal. Hasil penelitian ini juga merekomendasikan bahwa pemanfaatan yang tepat berdasarkan kajian nilai penting adalah pemanfaatan yang berhubungan dengan ilmu pengetahuan.

\section{Daftar Pustaka}

The Fossil Vertebrates And Stone Tools In The Walanae Valley In South Sulawesi [Celebes]. Modern Quaternary Research in Southeast Asia 4.

Bellwood, Peter 1985, Prehistory of The Indo-Malaysian Archipelago, Sydney.

Berg, Gert van den 1999, The Late Neogene elephantoid- 
bearing faunas of Indonesia. Scripta Geol., 117

Berg, Gert van den, et al. 2001, The Late Quaternary Paleogeography of Mammal Evolution in The Indonesian Archipelago, dalam Paleogeography, Paleoclimatology, Paleoecology, 171, 2001, 385-408.

Bulbeck, David, 2008, An Archaeological Perspective On The Diversification of The Languanges Of The South Sulawesi Stock, dalam Truman Simanjuntak [edt.] Austronesian in Sulawesi, Depok, CPAS, hal: 185-212. ///

Clason, A.T., 1976. A preliminary note about the animal remains from the Leang I cave, south Sulawesi, Indonesia. - Mod. Quatern. Res. SE Asia, 3: 5367.

Falconer, H. \& P.T. Cautley, 1846. Fauna Antiqua Sivalensis, being the Fossil Zoology of the Sewalik. Hills in the North of India (plates only). — Smith, Elder, London.

Glover, I. C., 1981. Leang Burung 2 : An Upper Palaeolithic Rock Shelter in South Sulawesi, Indonesia. Modern Quartenary Research in Southeast Asia 6: Hal. 1-38.

Harjasasmita, S. 1982, Kehadiran Elemen Fauna Vertebrata Asia Di Sebelah Timur Garis Wallace Pada Kala Plestosen, dalam Pertemuan Ilmiah Arkeologi II, Proyek Penelitian Purbakala, Jakarta.

Heekeren, H. R. van. 1958. The Tjabenge flake industry from South Celebes. Asian Perspectives 2:77-81. 1972. The Stone Age of Indonesia. 2nd ed. The Haque Martinus Nijhoff.

Hooijer, D.A. 1948, Pleistocene vertebrates from Celebes, Celebochoerus heekereni nov.gen.nov.spec. Proceedings Koninklijke Nederlandsche Akademie van Wetenschappen 51:1024-32.

-, 1950. Man and other mammals from
Toalian sites in south-western Celebes. - Verh. Kon. Ned. Akad. Wet., Afd. Natuurk., 2, 46: 1-164.

Morwood, M.J., van Oosterzee, P., 2007. The Discovery of the Hobbit: The Scientific Breakthrough that Changed the Face of Human History. Random House, Sydney, Australia.

Sarasin, Paul and fritz, 1905 Reisen in Celebes. Zweiter band. Wiesbaden: C.W. Kreidel's Verlag.

Sartono, S., 1982. Genesa Danau Tempe, dalam Pertemuan Ilmiah Arkeologi II, Proyek Penelitian Purbakala, Jakarta.

1979, The age of the vertebrate fossils and artefacts from Cabenge in South Sulawesi, Indonesia, Modern Quaternary Research in Southeast Asia 5:65-81.

Sjahroel, A.A. 1970, Report on the preliminaty geological survey of the centralpart of Kabupaten Soppeng, south celebes. MS, Direktorat Geologi Bandung.

Soejono, R.P. 1982, Data Baru Tentang Industri Paleolitik Di Indonesia, dalam Pertemuan Ilmiah Arkeologi II, Proyek Penelitian Purbakala, Jakarta.

Soejono, R.P. ed. 1991, Sejarah Nasional Indonesia I. Jakarta, Balai Pustaka.

Sondaar, P.Y. 1981, Geochelone faunas of the Indonesian archipelago and their paleographical and biostratigraphical significance. Modern Quaternary Research in Southeast Asia 6:11119 .

Whitten, Anthony. J. 1987. Ekologi Sulawesi. Gadjah Mada University Press, Yogyakarta. 